Milan Rapajić ${ }^{1}$

Milivoje Lapčević ${ }^{2}$

University of Kragujevac,

Faculty of Law

Violeta Miladinović ${ }^{3}$

Local Tax Administration,

Municipality of Ćuprija
ORIGINAL SCIENTIFIC ARTICLE doi:10.5937/ekonomika1901035R

Received December, 05, 2018

Accepted: February, 21, 2019

\title{
DINAMISM OF PROPERTY TAX REFORM IN SERBIA - ADMINISTRATIVE AND FISCAL ASPECTS
}

\begin{abstract}
Since the introduction of property taxation in Serbian legislation, the tax system has been the subject of reforms a number of times for the purpose of its harmonization it with European Union standards. Initial changes were almost unnoticiable, while the latest modifications in the law attracted considerable interest of the tax policy creators, financial experts, as well as the taxpayers themselves because they introduced a new method of determining the tax basis which has increased the overall tax liabilities at annual level. Bearing in mind that the property tax generates local revenue and that local governments are in constant need for additional resources, the methodology of determining the tax liability should be based on the principle of equity and equality in order to ensure an ultimately efficient tax collection. In this paper, the authors will attempt to analyze both positive and negative aspects of improving the property tax system through a number of years, as well as to propose some solutions for the future reform of this system. By means of fiscal decentralization, this revenue plays an important role in financing local expenditure, while its abundance directly secures a larger autonomy of local self-government units, making them less dependable on the funds coming from the state budget.
\end{abstract}

Key words:property tax, tax reform, tax basis

JEL Classification: $H 2$

\section{ДИНАМИЗАМ РЕФОРМИ ОПОРЕЗИВАҢА ИМОВИНЕ У СРБИЈИ - АДМИНИСТРАТИВНИ И ФИСКАЛНИ АСПЕКТИ}

\begin{abstract}
Апстракт
Од увођења пореза на имовину у српско законодавство, систем опорезивања је неколико пута реформисан са ииљем његовог прилагођавања стандардима Европске уније. Почетне промене су биле прилично неприметне, да би се након последюе измене закона значајно повећало интересовање креато-
\end{abstract}

\footnotetext{
${ }^{1}$ mrapajic@jura.kg.ac.rs

${ }^{2}$ mlapcevic@jura.kg.ac.rs

${ }^{3}$ veta187@hotmail.com
} 
ра пореске политике, финансијских теоретичара и самих пореских обвезни$\kappa а$, из разлога што је нови начин утврђивања пореске основице донео и знатно већа пореска задужења на годишњем нивоу. Имајући у виду да је порез на имовину локални приход и да су потребе локалних заједнища све веће, методологија утврђивања пореске обавезе би требала да се заснива на приниипу правичности и једнакости како би крајьа наплата пореза била ефикаснија. У овом раду ће бити сагледане позитивне и негативне стране унапређења система опорезивања имовине кроз године примене, као и предлози будуће реформе. Фискалнм децентрализацијом је овај приход заузео значајно место у финансираюу локалних расхода, а юегова већа издашност директно обезбеђује већу самосталност јединица локалне самоуправе и мање ослањање на приходе из државног буиета.

Кључне речи: порез на имовину, пореска реформа, пореска основица

\section{Introduction}

Property tax in the Republic of Serbia represents a nominal tax since it is not paid from the property substance, but from the taxpayers'means (Lovčević, 1997, p. 116).It is usually, but not always, a local tax, based on the property value determined at annual level for both natural and legal persons. Given the fact that it can provide a stable source of income, it is particularly appealing to local governments and plays an important role in the decentralization of state power and the autonomy of the local government units.

In practice, the tax is considered to be an instrument for securing necessary budget funds, but it is also used for achieving other goals (Kulić, 2009, p. 43). According to taxation principles, it needs to be large enough to cover local government expenses, as well as sufficiently flexible to quickly adapt to all changes in terms of its increase or decrease for the purpose of obtaining a balanced budget.

The tax reform in the Republic of Serbia should be viewed in the context of the harmonization of its system of public revenue to European Union standards. Many global studies have documented a discrepancy between an administrative practice and legally established standards (Fisher, Fairbanks, 1967, p. 48). In order for this tax to become one of the essential sources of financing local governments on long term basis, the first step is to change the legal framework.Unless the tax structure is made simple enough togain trust of taxpayers and to allow an efficient administration, the sole reform does not mean much and is doomed to fail (Almy, 2013, p. 61).

In its basis, a tax reform generally means the change of taxpayers'and tax authorities'conduct. It is much more profitable when people voluntarily accept to follow regulations, than to force them to do so using unpopular measures to ensure compliance with law. Property tax proponents have advocated for a long time its reformin order to reach its highest potential (Rozner, 2009, p. 1). The best practice of both administrative and political tax reform has already been identified; however, due to specific nature of local government units, it does not mean that this practice could be successfully implemented inall of them, although some of its general rules could be used as guidelines for an efficient property taxation.

The tendency of the state government to influence the change of the local tax 
regime may have impact on the firmly established wholeness of the political system, even in stable political conditions (Youngman, 2006, p. 2). Therefore, the comparative analysis of successful and less successful international property tax reforms are of great significance for assisting the countries in the attempt to revise their own tax systems or are pressured to make fundamental changes in that context in near future. The challenges that a tax reform brings cannot be resolved in a short run, but rather require the preparation of strategic solutions which are specific for different countries (Norregaard, 2013, p. 34).

The most frequent problems related to tax reform are: the lack or incompleteness of information related to the actual facts which leads to incorrect calculation of the tax basis, insufficient financial and human resources and inadequate administrative capacity for an efficient implementation of reform activities (Rosengard, 2012, p. 14). The justifications for launching a tax reform that would unquestionably improve fiscal performance are social equality, economic efficacy and administrative cost effectiveness.

With the adoption of the Law on local government finance, the property tax became the principal revenue for the local level of government, while the jurisdiction for its administration was awarded to local tax departments. Since the deadline for taking over this jurisdiction was January $1^{\text {st }}, 2009$, in this paper the authors will present the most significant reform outcomes which have marked a decade of the work of local tax administrations.

\section{Qualitative aspects of initial property tax reforms}

The comprehensive tax reform from the beginning of the $90 \mathrm{~s}$ also included the area of property tax which was introduced in our tax system on January $1^{\text {st }}, 1992$. The tax incomehas been used as the principal source for financing of local self-government units and its significance reflects the fact that the properties cannot be moved elsewhere in order to avoid paying this tax (Mark, Carruthers, 1983, p. 45).

The property tax is paid on the basis of the property ownership (Popović, 1999, p. 256). For natural persons, the tax basis represented the product of an average market price of the square meter of the property in the particular local self-government unit, property's usable space, the location coefficient and the property's quality coefficient. The amount of amortizationisdeducted from the calculated value which further significantly reduced the property's value tothe extent much below the market value of the taxed property (Kecman, 2001, p. 120). At the beginning the amount of amortization was $70 \%$, but following the change of law, this reduction was performed according to $1,5 \%$ amortization rate by applying the proportional method. As of 2010, the property's value was reduced according to $0.8 \%$ amortization rate by applying the proportional method, with the upper limit not exceeding $40 \%$. There was no need to establish the tax basis for taxing properties belonging to legal persons, since the values of these properties were established in their business records, taking the values recorded on December $31^{\text {st }}$ of the year preceding the year for which the property tax was being established.

Almost all contemporary tax systems offer to their taxpayers various tax reliefsreducing their tax liabilities (Popovic, 1997, p. 192). Reviewing the tax system in Serbia, it can be concluded that these reliefs have been established under the influence of various political, economic, social, fiscal, ecological and administrative factors, and 
needed to be modified from time to time (Bahl, 2009, p. 25). Tax credits significantly contributed to the inequality of taxation system in Serbia. In majority of tax systems, the property tax is linked exclusively to the property's characteristics and it does not take into account the specific status of its owner.The initial tax regulations prescribed that the property's owner with three family members could have a tax credit up to $70 \%$, which was, perhaps, a unique case in the international property taxation practice. Such tax reduction was more the result of the state's welfare strategy, than its taxation policy. The regression was also significant since the taxpayers with the most expensive properties could score the largest tax credit (Altiparmakov, 2011, p. 90). The current law, which foresees that only the property's owner is entitled to the tax reduction of $50 \%$, not exceeding the amount of $20.000 \mathrm{RSD}$,did not mark a significant change in relation to the level of tax credit, which remains considerably high. However, according to some estimates, almost 95\%of households in Serbia cannot achieve itsmaximum which has made this tax relief less equitable. Namely, our system of tax reliefs is so comprehensive and "generous" rendering the property tax income fiscally insignificant from the aspect of the entire tax system (Bućić, 2010, p. 31).

The property tax reformfrom 2011 imposed the restriction in the growth of property tax for natural persons, so the tax liability established for that year could not exceed $60 \%$ of the tax liability that was established for 2010. The similar situation was recorded in 2012 when the amount of the tax liability for a certain property could not exceed the tax amount that was established for that property in 2011. These legal provisions were favourable for taxpayers and therefore, these changes in law went unnoticed. However, the income generated from collecting property taxes in Serbia was far less than the property tax income in the countries of European Union.

\section{Mini-reform endeavour related to property taxation}

One of the best solutions of the problem related to increasing the local budget is connected to the property tax income since it is considered to be insufficiently exploited in majority of countries worldwide, and, therefore, many countries have made significant endeavours to make considerable changes of their tax system (Ciprian, 2015, p. 66). The starting point of each tax reform is the calculation of the tax basis and the previous tax reforms in Serbia obviously did not do much in this field. The major flaw was encountered in the calculation of the average market price since none of these reforms used the most reliable parameter for estimating the tax basis for absolute rights transfer tax. In addition, the decision to keep the quality coefficient and high rate of amortization made the overall tax basis rather underestimated.

For many years there had been much talk in the Republic of Serbia about the necessity to launch property tax reform. In 2013, the tax law was finally amended and its application began in 2014. One of the major motivation for initiating the tax reform was the amount of collected revenue which was found to be insignificantly low, almost symbolic (Buzu, Mccluskey, Franzsen, 2012, p. 20). The reasons for changing the law were related to the issues of integratingthe construction land use charge and the property tax, more equitable distribution of tax liability - proportional to the taxpayer's economic status, enhancing the certainity and predictability of the overall amount of public 
expenses, as well as decreasing the administrative costs. The law was significantly changed in relation to the subject of taxation and the calculation of the tax basis, while it was left to the local self-government units to further adopt bylaws important for determining the amount of tax liabilities.

The legislator prescribed in details the methods and conditions for passing these bylaws, setting the deadline for their adoption - November $30^{\text {th }}$ of the year preceding the year for which the tax basis was being determined. In order to achieve the data transparency, the legislator imposed the obligation that these acts should be publicly displayed as legally prescribedand on the Internet web pages of local self-government units. The construction land use charge and the property tax were integrated which left the local governments without a major source of their own funds. The ideal scenario of a simple replacement of the charge with the increased amount of property tax could not be exercised since it was not possible to collect the increased tax liability from the individual taxpayersand have an "all win situation" (Arsic, Vasiljevic, Bucic, Randjelovic, 2004, p. 43). The process of integrating the charge and tax fees raised many questions related to its justification since the income generated from collecting the charge at the time of its establishing was much higher than the overall tax revenue (Miladinovic, 2015, p. 47). The reform was aimed at providing tax reliefs for businesses by imposing additional fiscal liabilities on natural persons.

Chart no. 1 The overview of the property tax income and theincome generated from

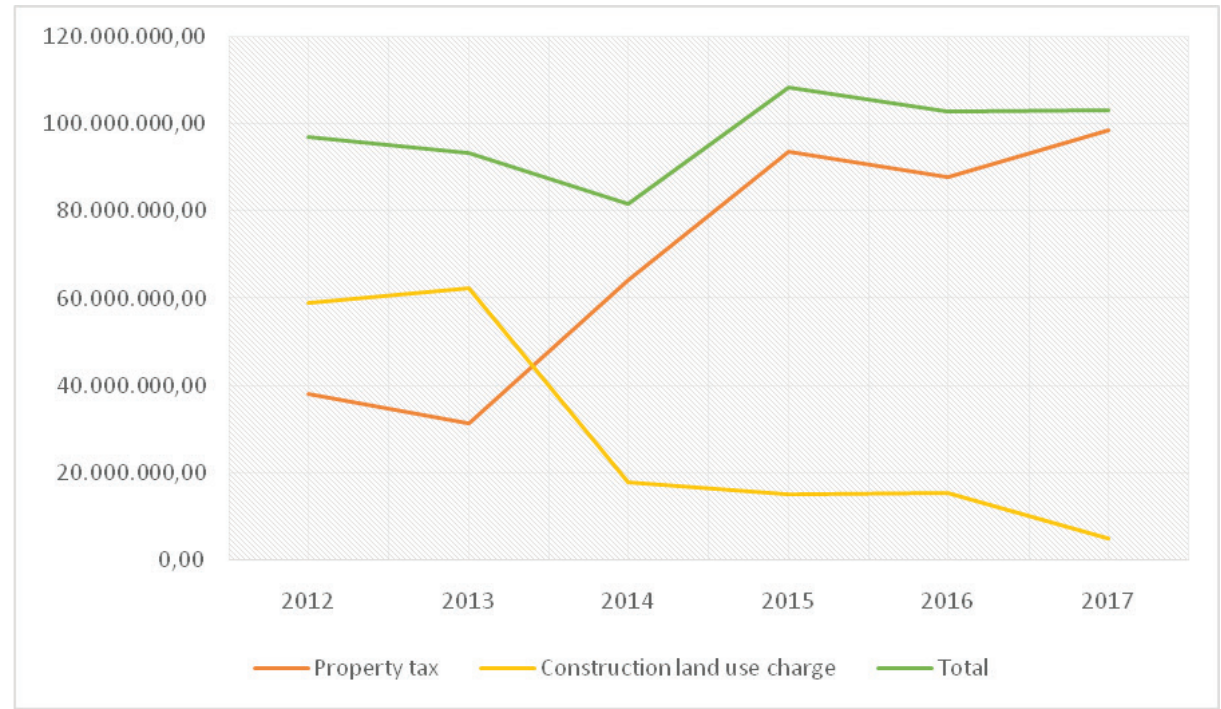

Source: The chart was made based on the data obtained from the Ministry of Finance Treasury Department and the Local Tax Administration of Ćuprija

The calculation of the tax basis was changed and local self-government units were awarded the jurisdiction to establish on annual basis the average price of the square meter of a particular property on their territory taking into account the method which was prescribed in details in the tax law. The amortization rate was set to $1 \%$ on annual 
basis, with the maximum of $40 \%$, but with no obligation to implement it. The property quality coefficient was removed, while the property location coefficient was replaced by establishing the territorial zones in local self-government units. The tax rates remained unchanged, while additional tax reliefs were added. However, the largest charge referred to the method of calculating the tax liabilities of the taxpayers who keep business records, that is of legal persons which are now under obligation to use the method of self-taxation.Asfor natural persons, the major change of the law was concerned with the categorization of properties. Namely, the buildings intended for recreation and vocation, as well as the category"other buildings" were removed from the previous categories of properties, so each of such property needed new classification and new calculation of tax liabilities. Generally speaking, the property tax should be paid foreach existing property, except for the exemptions defined by law. There appeared the problem of an adequate categorization of properties since the tax application form could not provide the insight what type of buildingis being taxed, that is whether the specific building is a summer house, shed, storage, or similar structure, so that they could be classified into defined property categories. Thus, the field inspection showed that some sheds and summer houses could have been classified into residential structures, or some huts and storages into garages. These examples from practice showed that some adjoining buildings used for living were taxed as garages since they could not meet the conditions of residential structures, and therefore, their estimated average price was much lower.

The property tax basis is determined according to the property's usable space and the average price of the propertyin a particular territorial zone. Thus calculated value of the property, except for land, can be reduced for the amortization rate of up to $1 \%$. The property's usable space, which is the subject of taxation,includes: terraces, cellars, storages, lofts, basements, build in balconies and renovated attics. Thus, this law did not make exceptions in regards to cellars, basements and storages which used to be taxed at reduced rate - their full space being now the subject of taxation. The average price of the square meter of the property per a territorial zone is determined by bylaws passed by relevant bodies of individual local self-government units. The average price is calculated on the basis of the price of that type of property, sold in that particular zone in the period from January $1^{\text {st }}$ to September $30^{\text {th }}$ of the current year. The law does not regulate the methodology for determining this price and its correct calculation dependson a continuous and timely collection of available data within legally prescribed time frames (Miladinovic, 2018, p. 96).

In order to determine the average price of the square meter of the property per a territorial zone of a local self-government unit, it is necessary to have at least three sales of this type of property in that particular zone. In case this condition is not met, the average price is determined based on the average price of the properties sold in the bordering zone. The bordering zone may be in the same local self-government unit or in the neighbouring local self-government unit. In case there were no three sales of properties in these zones either, so the average price could not be determined under this condition either, then, the average price from the current year is taken for determining the property tax liability for the next year.

Although this new legal solution for determining the average price may seem simple at first sight, in practice it proved to be difficult. In small local self-government units it is almost impossible to accomplish the sale of three properties from all listed 
categories, so they cannot meet this precondition for determining the average price of the given category of property. Although the legislator had to find the way to integrate the construction land use charge and the property tax and ensure that the newly established tax liability is not too low to cause alarge debt in the local governments' budgets, itdid not take into account the reallife situation when it decided to use this method of determining the average property price.

The implementation of the long-awaited changes in the calculation of the property tax for legal persons started in 2014. The tax basis for the properties whose values are presented in business records according to the fair value method, in line with international accounting standards, that is, the international standards of financial reporting and accepted accounting policies, represents a fair value of the property recorded on the lastday of the current business year in the legal person's business records. For the taxpayers which do not keep their business records according to this method, the tax basis is established according to the property's usable space and average market price. Certain properties are exempt from this calculation on the basis of their intended use and their accounting value recorded in the taxpayer's business records on the last they of the business year is taken as the tax basis for establishing the tax liability. If the taxpayer presents these properties in its business records separately from the land they are built on, the sum of the accounting values of the buildings is taken as the tax basis for calculating the tax liability, while the value of the land is calculated by applying the average price principle according to the decisions adopted by local self-government units. If the buildings and the land are presented as a whole, then, the value of the land is appraised by a certified expert in the field of construction engineering based on the data recorded on the last day of the business year for the current year. As for the land without built structures, its value is taken as the tax basis for calculating the tax liability.

The issue that could not be avoided in any tax reform is related to calculating the tax basis for agricultural and forest land. Since the annual cadastral revenue was not regularly revaluated, a great number of local self-government units did not establish the property tax liability for this type of land. Absurdly enough, this tax was presented in local self-government units' business records as their expenditure, since the costs of their accounting and collecting were much higher then the amounts of the actually generated revenue. Moreover, there is no reason why this kind of property should not be taxed, as well. Thus, before 2014 the agricultural and forest land represented an unused taxation resource, but then, in 2014, this issue came into focus of the legislator which resulted in the change of the method of calculating the land tax that was incorporated in the new tax law. These novelties related to the new method of calculating the land tax contributed to much higher annual tax liabilities for the agricultural and forest land owners.However, the increase of this tax liability did not mean the increase of tax revenue. The new law provisions contained some inconsistencies which have had a great impact on the taxpayers' decisions related to paying this liability. The examples from practice show that these provisions have some flaws which adversely affect the tax collection and that the categorization of the property from the earlier period seemed to be a more adequate solution. However, although the changes of the tax law very soon started to show some deficiencies, this reform, nevertheless, successfully resolved many problems and anomalies existing in the previous tax law (Kecman, 2013, p. 79). 


\section{Controversies related to the announced property tax reform}

With the development of the new fiscal policy, the property taxation has assumed new, more significant role; now, it does not only serve as the instrument for generating income, but also as an additional means of decentralization (Malme, Youngman, 2001, p. 1). After a four-year period of implementing a new system of establishing property tax liabilities, the Ministry of Finance published a draft version of the modified Property Tax Law, intended to come into effect in 2019. The previous changes of the law, from the very beginning of its implementation, were met with criticism from both taxpayers and the professional public, so much more was expected to come with this reform, to come sooner at first place.The methodology of establishing the tax basis was changed in the previous law, but the new procedure has created considerable problems to legal persons who applied the self-taxation methodology. In addition, local self-government units also encountered difficulties with establishing the average price of propertiesper territorial zones. Therefore, it is no wonder that that the upcoming reform is in the focus of great interest, particularly of the legal persons and the owners of business premises whose property tax liabilities have been largely increased with the application of 2014 tax law.

New modifications of the tax law are primarily aimed at amending and completing the old provisions which were inconsistent or ambiguous, thus reflecting the intention of the authorities to resolve the problems encountered in the practice in the past four years. The decision to change the property categories and introduce again the category of "other buildings" that would include all the buildings and structures not intended for living or conducting business is welcome as a positive change. Garages and parking places no longer constitute a separate category of property, but were added to another group. However, since garages always belonged to a separate group of properties, the opinion is that they should remain as such and that other auxiliary structures, such as sheds, storages, etc. should be included into the category of "other buildings".

The restrictions related to land taxation remain in force and a large number of land owners will not be paying land tax since their property does not exceed the surface of 10 ares.The professional opinion is that only large land lots (over 10 ares) should be the subject of taxation, which is contrary to fiscal logic (Stojanovic, Lapcevic, 2013, p 41 ) and, therefore, this provision should be changed. If there are no restrictions related to the size of the buildings to be taxed, there should be no restrictions related to the size of the land lots, and, in such a case, the implemented integration of the construction land use charge into the property tax would be justifiable

Another novelty in the draft version of the property tax law is the $40 \%$ reduction of the tax basis for the buildings whose ground floors are below the land surface, whose adjoining awningstructure exceeds than $10 \mathrm{~m} 2$, as well as for the buildings intended for sport, recreational and fair activities. Cellars became the subject of taxation as fully usable space in 2014 tax law. However, since this is the part of the property not used as frequently as other rooms and facilities, it would be logical that this space is taxed according to reduced rate.

The current provisions of the law regulate the moment when a certain tax liability comes into effect, while the modifications of this law also foresee the conditions for terminating this obligation. Due to frequent confusions arisen in practical application of these provisions, the working draft of the new law more closely describes the situations 
when a tax obligation is assumed and when it ceases to exist. However, the new provisions do not clarify a dilemma related to meeting the conditions for taxing the property in terms of its furnishing, as well as in what cases a property ceases to exist and is no longer the subject of taxation.

One of new solutions found in the draft version of property tax law is related to the tax rates for establishing the property tax liability of natural persons. The progressive rate remains in effect, bit it is now reduced for the properties whose tax basis exceeds 10.000.000,00 RSD. If these provisions are adopted, this rate will be $0,40 \%$ for the tax basis of up to $50.000 .000,00 \mathrm{RSD}$, that is $0,5 \%$ for the tax basis exceeding $50.000 .000,00$ RSD. The legislator's intentions in this case are not quite clear since natural persons who own more valuable properties should be paying larger taxes. However, this provision puts such taxpayers in a favorable position.

The draft version of the new tax law no longer foresees a possibility that the tax basis for legal persons can be a fair value, but it is now calculated as the product of the property's usable space and the average market price, reduced for the amount of amortization. Thus, the methodology of calculating the tax basis for legal persons became equal to the one used for natural persons, but the provisions regulating a special category of properties for which the tax basis is determined according to their accounting values, still remain in effect.

The practical application of the property tax reforms have shown that very often it was difficult to implement them in real life (Slack, Bird, 2014, p. 2). As soon as this working draft was made public, it received a lot of criticism, causing it to be replaced by the second working version after two months. However, there is a great probability that this second version will be the final one since the beginning of its implementation is foreseen for January 2019.Majority of the changes that were proposed in the first working version of the new tax law were removed from the second draft, so it can be concluded that there will be no radical changes of the current law related to the method of calculating the tax basis. This means that the key deficiencies encountered in the current law will not be eliminated and the amounts of tax liabilities will remain almost unchanged in the next years.

Another tax law novelty is that paths, parking places, polygons, fences, garden pools, fountains, garden fireplaces, children's playgrounds, etc. will become the subject of land taxation. The new provisions describe in more details the property's usable space, while in the property categorization, the phrase "other land' replaces the phrase "other buildings". It is going to be very difficult to determine the average price of "other land" since in practice, during sales, this land has never been distinguished from other types of land: construction, agricultural or forest land. As for the land without built structures which is used for growing plants, tree seeding and landscaping, the local selfgovernment units are given a possibility to decide whether they will tax it as agricultural or forest land. One of the changes which will definitely provoke critical remarks and dissatisfaction among taxpayers is related to taxes on unfinished buildings, that is the properties under construction which have a roughly built frame structure. Bearing in mind that there is a great number of such properties in the Republic of Serbia which have been left unfinished for a long time, this decision is justifiable from the aspect of a fair taxation policy, particularly if we take into account that the current provisions of the property tax law foresee taxes on ruined properties. 
It was expected that the new property tax reform would resolve the problems that the local self-government units have been facing in the previous years; however, the proposed working draft of the modified law does not reflect such intent of the legislator.

\section{Conclusion}

The aim of every property tax reform has been to improve the existing taxation system so that it can generate a larger income and thus contribute to a larger financial autonomy of local self-government units. The results of the initial reforms had positive financial effects, but still insufficient to achieve formerly set goals. The application of new legal provisions pointed to the necessity for further reforms of the tax system aimed at rather more accountable management of fiscal policy by local self-government units and creating the budget aimed at more rational planning of revenue and expenses.

The previous modifications and amendments of the tax law brought the cancellation of the construction land use charge, which was a big change in the financial system of local self-government units. Before its integration into the property tax, natural persons generated larger tax income, while the legal persons generated larger income from construction land use charge.

The current situation shows that natural persons now have larger tax liability, while legal persons' annual tax burden is decreased compared to the period when this liability was established.

Today, the average price of the property's square meter is different depending on the category ofthe property it belongs to, while the former law recognized only one average market price applied to all types of properties. The cancellation of the corrective quality coefficient which contributed to lower tax basis resolved the problem of reduced tax basis, but not in the way to justify the integration of construction land use charge and property tax, particularly when it comes to the fact that the land lots not exceeding 10 acres are still exempt from taxation.

The methodology used for establishing an average market price of certain categories of properties was designed for "ideal conditions" which practically do not exist. In the Republic of Serbia, there is a number of small local self-government units which have difficulties in meeting the legislator's conditions of an average price based on at least three sales of a certain category of properties during a certain period of time. Although the legislator foresaw the existence of such cases, the question remains whether the average pricescalculated in this alternative way are realistic and justified in less developed regions.

The decision that all local self-government units are under obligation to publish all parameters used in establishing the property tax liabilities for the following year until November 30th of the current year, is viewed as a positive change. The new method of establishing the property tax basis for natural persons and the new tax application forms which were modified as a result of the cancellation of the quality coefficient, facilitated the process of recording new taxpayers by expending the scope of properties due for taxation. As for legal persons, the change of tax application forms resulted in many problems and after a four-year period of applying the self-taxation procedure, there is still a large number of taxpayers whoare submitting incorrect or incomplete applications 
which entails a comprehensive tax inspection. Also, there has been a number of cases of the abuse of the "fair value' principle, since this methodology was not correctly presented in the taxpayers' business records.

The first proposed draft version of the property tax law has positive aspects in terms of introducing the category of "other buildings", as a separate category of properties which would provide a more equitable method of taxation in terms of their looks and usability, but explanatory provisions could bring many problems in their practical application. The removal of the "fair value" principle in taxation of legal persons' properties is viewed as a justified solution that can prevent the abuse of its arbitrary application for the purpose of decreasing tax liabilities.

The second draft version contains very few changes compared to the current law provisions which sends a clear message that the legislator is not ready to implement a serious reform of the property tax law. The introduction of the category of "other land" will not contribute much to the increase of tax income, since this provision will be almost inapplicable in practice. The financial effects of the decision to tax unfinished buildings will not be immediately noticed, butit could bring positive outcomesif theseprovisions are strictly implemented in along term period and if they are equally applied to all taxpayers who own this category of properties. Given the fact that the price of the construction land is much higher than the price of agricultural or forest land, the decision to apply the price of agricultural and forest land for determining the tax basis for the land without built structures used for growing plants, tree seeding and landscaping, is reasonable.

The implementation of the modified and amended tax law provisions has shown their both positive and negative sides pointing to the fact that there is still place for some improvements, that is for the new reform of the property tax system in the Republic of Serbia.

\section{References}

Almy, R. (2013). Property Tax Regimes in Europe. Nairobi. UN-HABITAT.

Altiparmakov, N. (2011), Poreska pravičnost glavnih poreskih oblika u Srbiji, Kvartalni monitor, 24, p. 85-93.

Arsić, M., Vasiljević, D., Bućić, A., Ranđelović, S. (2014), Analiza mogućnosti za kompenzaciju prihoda od naknade za korišćenje građevinskog zemljišta, Belgrade, Standing conference of cities and municipalities.

Bahl, R. (2009). Property Tax Reform in Developing and Transition Countries, Washington D. C. The United States Agency for International Development (USAID).

Bućić, A. (2010), Kako do reforme poreza na imovinu, Lokalna samouprava-Propisi i praksa, 3, p. 29-35.

Buzu, O., Mccluskey, W., Franzsen, R. (2012), Real Property Assessment and Taxation in the Republic of Moldov, Journal of property tax assessment and administration, 9(4), p. 5-23.

Ciprian, S. (2015). A comparative Analysis of Property Taxation Within European Union, International Journal - VALLIS AUREA, 1 (1), p. 65-73.

Fisher, G., Fairbanks, R (1967), The Politics of Property Taxation, Administrative Science Quarterly, 12 (1), p. 48-71. 
Kecman, M.. (2011), Periodični porez na imovinu u Republici Srbiji, Računovodstvo, $55(5 / 6)$, p. 117-126.

Kecman, M. (2013), Promene u poreskom sistemu Srbije, Računovodstvo, 57(5/6), p. 69-80.

Kulić, M. (2009), Finansijska i ekonomska načela oporezivanja, Škola biznisa, 2, p. $42-49$.

Lovčević, J. (1997),Institucije javnih finansija, Belgrade, Službeni list SRJ

Malme, J., Youngman, J. (2001), The Development of Property Taxation in Economies in Transition. Washington, D.C. The World Bank.

Mark, J., Carruthers, N. (1983), Property values as a measure of ability-to-pay: An empirical examination, The Annals of Regional Science, 17 (2), p. 45-59.

Miladinović, V. (2018), Aktivnosti lokalne samouprave u naplati poreza na imovinu, Doctoral dissertation, University of Kragujevca Faculty of Law .

Miladinović, V. (2015), Integracija naknade za korišćenje građevinskog zemljišta u porez na imovinu, Pravo-teorija i praksa, 32(5/6), p. 40-49.

Norregaard, J. (2013), Taxing Immovable Property, Revenue Potential and Implementation Challenges, IMF Working Paper, 13/129, p. 2-42.

Popović, D. (1997), Nauka o porezima i poresko pravo, Belgrade, COLPI, Budapest, Savremena administracija d.d.

Popović, D. (1999), Poreski sistem, Belgrade, Dosije Beograd.

Rosengard, J. (2012).The Tax Everyone loves to Hate: Principales of property Tax Reform, Mossavar Rahmani Center for Business and Government. Harvard Kennedy School. Cambridge.

Rozner, S. (2009). Implementing Property Tax Reform, Best Practices in Fiscal Reform and Economic Governance. USAID.

Slack, E., Bird, R. (2014). The Political Economy of Property Tax Reform.OECD Working Papers on Fiscal Federalism No. 18,p. 2-36.

Stojanović, P., Lapčević, M. (2013),Kvalitativni aspekti majskih promena poreskog zakonodavstva. Pravni život, 62 (11), p. 33-44.

Youngman, J. (2006). The Property Tax in Development and in Transition, Andrew Young School of policy studies, Working Paper 06-36, p. 1-19. 